\title{
Twenty Years of the Shanghai Cooperation Organization: Achievements, Challenges and Prospects
}

\author{
Yamei Xue $^{1}$ (), Benjamin Mwadi Makengo² \\ ${ }^{1}$ Early Warning Academy, Wuhan, China \\ ${ }^{2}$ School of Politics and International Studies, Central China Normal University, Wuhan, China \\ Email: 654379536@qq.com, benjaminmwadi@yahoo.com
}

How to cite this paper: Xue, Y., \& Makengo, B. M. (2021). Twenty Years of the Shanghai Cooperation Organization: Achievements, Challenges and Prospects. Open Journal of Social Sciences, 9, 184-200. https://doi.org/10.4236/jss.2021.910014

Received: September 10, 2021

Accepted: October 19, 2021

Published: October 22, 2021

Copyright (อ 2021 by author(s) and Scientific Research Publishing Inc. This work is licensed under the Creative Commons Attribution-NonCommercial International License (CC BY-NC 4.0). http://creativecommons.org/licenses/by-nc/4.0/ (c) (i) (s) Open Access

\begin{abstract}
The Shanghai Cooperation Organization (SCO) started from solving boundary issues, grew from counter-terrorism cooperation, developed and deepened in political, economic, cultural, educational and other fields of cooperation, and gradually developed into a new model of multilateral cooperation. This paper intends to outline the main achievements, challenges and prospects of the SCO after the two decades of its existence. After debate and discussion, the results that emerge from this paper show that over the past 20 years since the SCO establishment in June 2001, its concept of cooperation has been constantly enriched and developed. Its cooperation mechanism has been constantly enriched and improved; and its areas of cooperation have been expanded. However, with its development over time and the advancement of its cooperation practices, the SCO also faces challenges and development difficulties on its way forward; these include the facts of: the intensification of great power game in the region, the weakness of the sense of community between its member states and the transformation of cooperation pattern faces after expansion. Looking ahead, the Shanghai Spirit will guide its multilateral cooperation vision. The SCO mechanism provides an important guarantee for its multilateral cooperation ahead. The new type of international relations will serve as an important driving force for its multilateral cooperation vision. Based on our findings, this paper reasoned that the SCO is fully capable of exerting greater influence and delivering greater results in the years to come.
\end{abstract}

\section{Keywords}

Shanghai Cooperation Organization, Multilateral Cooperation, SCO’s Achievement-Challenges-Prospects 


\section{Introduction}

The establishment of the Shanghai Cooperation Organization (SCO) is a major international event in contemporary international political life. Twenty years after its establishment in June 2001 (Jia, 2007), the SCO has become the largest and most populous regional cooperation organization in the world, covering three-fifths of the Eurasian continent and with a population of over three billion (IISS, 2018). The establishment of the SCO is of great significance to promoting peace and security, prosperity and development in Central Asia, Eurasia and the world at large. Based on the existing literature, also following Boland's (2011) observation, the writings that address the issues surrounding the SCO, often do so with a great deal of subjectivity. Various scholars bring up different points of view regarding the major issues surrounding this organization. Among these great questions that keep dividing various researchers, we are thinking here just of the one that is to know, if the United States, the European Union and NATO should be interested in the SCO or ignore it. Some see it as a "paper tiger" while others describe it with suspicion as a counterweight to NATO (Germanovich, 2008). Some others question whether it was a nascent military alliance and others also see it as a means for stability, peace, security and prosperity in the region. However, as Boland (2011) also argues, the activities and orientations of the SCO suggest that it is evolving into something more in the middle of these scholar's positions, in response to changing issues and games at the global level, and in the Eurasian region in particular. The obvious constant is that the vast majority of recent writings by various scholars around the world are increasingly focused on the issues surrounding China-Russia-India-Pakistan relations within the SCO and the security-related [issues] that the organization embraces (Fan, 2021; Wang \& Kong, 2019; Efremenko, 2019). While the primary facts [basics and fonts] about the organization do not attract enough scholars' attention [also found by Boland (2011).

Against this backdrop, this paper proposes to outline the major achievements, challenges and prospects of the SCO after the two decades of its existence. For twenty years after its establishment on June 15, 2001, it is also crucial to dwell on its evolution, especially in order to determine where the organization seems to stand and go. These just rise up the gaps that this paper intends to cover through the contributions and innovations that it tries to bring, proposing to outline a detailed summary of the achievements of the SCO over the last twenty years, while analyzing the existing challenges that the SCO faces and exploring the way of the SCO's further development. Hence, the central question of this paper, after twenty years of the existence of the SCO, what can we retain of its main achievements, challenges and prospects?

Apart from this introductory section, the rest of this paper is organized as follows. The second section provides a brief overview of the SCO. The third section outlines the main achievements of the SCO. The fourth section identifies the major challenges facing the SCO. The fifth section explores on the prospects of 
the organization. And finally, the last section is devoted to the conclusion.

\section{The Brief Overview of the Shanghai Cooperation Organization (SCO)}

The SCO is a permanent intergovernmental international organization, much of whose history is ostensibly tied to the rapprochement between Russia and China to cooperate on common geo-economical-strategic objectives for the long-term economic integration of the Asian continent (Rowden, 2018; SCO, 2021). Its birth dates back to 1996 via the establishment of a loose grouping between China, Russia and the three former Soviet Republics: Kazakhstan, Kyrgyzstan and Tajikistan. They met [in this loose grouping] to resolve border disputes, both old ones between China and Russia, and more recent ones that arose after the dissolution of the Soviet Union in 1991 (Rowden, 2018; SCO, 2021). The group first met in Shanghai and thus became known as the "Shanghai five" (Rowden, 2018). On June 15, 2001 in Shanghai, these "Shanghai five" decided to form themselves into a new permanent international organization, the SCO, with headquarters in Beijing (SCO, 2021). They added Uzbekistan the same year, becoming a group of six member states (SCO, 2021). The Charter of the Shanghai Cooperation Organization was signed at the SCO heads of state meeting in St. Petersburg in June 2002 and entered into force on September 19, 2003 (SCO, 2021). It is the basic statutory document that defines the goals and principles of the organization, as well as its structure and main activities (SCO, 2021). Inspired by the spirit of Shanghai, the SCO conducts its domestic policy on the basis of the principles of mutual trust, mutual benefit, equality, mutual consultation, respect for cultural diversity, and the desire for common development, while its foreign policy is conducted in accordance with the principles of non-alignment, non-targeting of third countries, and openness (SCO, 2021). Between 2004 and 2005, the SCO admitted Mongolia, Pakistan, India and Iran as non-voting "observer states". But via the historic Shanghai Cooperation Organization Heads of State Council meeting held on June 8-9, 2017 in Astana in June 2017, the SCO took a major step forward by formally admitting Pakistan and India as full voting members at the same time (Rowden, 2018; SCO, 2021). With the entry of India and Pakistan, the eight full members of the SCO now represent approximately $20 \%$ of the world's GDP and about $42 \%$ of the world's population, as well as four of the declared nuclear powers (Rowden, 2018). In the future, the SCO is considering admitting Turkey and Iran, as full members (Rowden, 2018). Thus, currently, the SCO has eight member states: the Republic of India, the Republic of Kazakhstan, the People's Republic of China, the Kyrgyz Republic, the Islamic Republic of Pakistan, the Russian Federation, the Republic of Tajikistan and the Republic of Uzbekistan; four observer states: Islamic Republic of Afghanistan, Republic of Belarus, Islamic Republic of Iran, and Mongolia; and six dialogue partners: the Republic of Azerbaijan, Republic of Armenia, Kingdom of Cambodia, Democratic Federal Republic of Nepal, Republic of Turkey, and Democratic Socialist Republic of Sri Lanka (SCO, 2021). 
Until further notice, the SCO claims to pursue the following main objectives: to strengthen mutual trust and neighborliness among member states; to promote their effective cooperation in the fields of politics, trade, economy, research, technology and culture, as well as education, energy, transportation, tourism, environmental protection and other areas; to make joint efforts to maintain and ensure peace, security and stability in the region; and to advance towards the establishment of a new democratic, equitable and rational international political and economic order (SCO, 2021). With regard to the organization and functioning of the SCO, it is worth noting here that the Heads of State Council (HSC) is the supreme decision-making body of the SCO. It meets once a year and adopts decisions and guidelines on all important issues of the organization (SCO, 2021). The SCO Heads of Government Council (HGC) meets once a year to discuss the multilateral cooperation strategy and priority areas of the organization, to resolve important economic and other cooperation issues, and to approve the organization's annual budget (SCO, 2021). The official languages of the SCO are Russian and Chinese (SCO, 2021). In addition to the meetings of the HSC and HGC, there is also a mechanism for meetings at the level of heads of parliament, secretaries of the Security Councils, ministers of foreign affairs, defense, emergency relief, economy, transportation, culture, education, and health care, heads of law enforcement agencies and supreme and arbitration courts, and attorneys general (SCO, 2021). The Council of National Coordinators of SCO Member States (CNC) serves as the coordinating mechanism of the SCO (SCO, 2021). The organization has two permanent bodies: the SCO Secretariat, based in Beijing [the SCO's main permanent executive body], and the Executive Committee of the Regional Anti-Terrorist Structure (RATS), based in Tashkent (SCO, 2021). The SCO Secretary General and the head of the SCO RATS Executive Committee are appointed by the Council of Heads of State for a three-year term on a rotating basis in Russian alphabetical order with no possibility of extension (SCO, 2021). They are backed by their assistants and Secretariat officials recruited from among the citizens of the organization's member states (SCO, 2021). Vladimir Norov (Uzbekistan) and Jumakhon Giyosov (Tajikistan) have held respectively the positions of secretariat general and directors of the executive committee of the regional anti-terrorism structure since January 1 , 2019 (SCO, 2021). In terms of external communication, the SCO cooperates well with a number of international, global and regional organizations, including the United Nations, the Commonwealth of Independent States, the Association of Southeast Asian Nations, the Collective Security Treaty Organisation, the Economic Cooperation Organisation, the Conference on Interaction and Confidence-Building Measures in Asia and the International Committee of the Red Cross (SCO, 2021).

\section{Main Achievements}

On the basis of our analyses, observations and facts, we identify three main 
achievements of the SCO after its twenty years of existence, which we propose to outline here in this point in the successive way, namely: The enrichment and development of cooperation concept (i), the enrichment and improvement of cooperation mechanisms (ii) and the extension of cooperation areas (iii).

\subsection{The Enrichment and Development of Cooperation Concept}

The fundamental reason why the SCO has maintained its vitality and become an influential regional international organization in the face of changes in the international landscape over the past two decades lies in the "Shanghai Spirit". "The Shanghai Spirit" is the spiritual home of the SCO, "a unique source of smooth development of the SCO, and an important guide for developing state-to-state relations, coping with global threats and challenges and resolving international differences" (CMFA, 2016).

The core of the Shanghai Spirit is "mutual trust, mutual benefit, equality, consultation, respect for the diversity of civilizations and pursuit of common development". The "Shanghai Spirit" was formed during the period of the "Shanghai Five" (Rowden, 2018). Two important documents of great significance were the Agreement on Strengthening Military Trust in Border Areas (1996) and the Agreement on Mutual Reduction of Military Forces in Border Areas (1997) signed by China, Russia, Kazakhstan, Kyrgyzstan and Tajikistan. The two documents broke through the traditional mode of cooperation and emphasized multilateral security cooperation on the basis of common interests, giving birth to the "Shanghai Spirit". With the development of the Times and changes in the international situation, the Shanghai Spirit has been enriched and developed. At the 2018 SCO Qingdao Summit, President Xi Jinping delivered an important speech entitled "carrying forward the Shanghai spirit and building a community with a shared future", in which he put forward the "five views", which added new content to the Shanghai spirit and promoted the building of an SCO community with a shared future. "Five views" specifically refers to: innovative, coordinated, green, open and sharing development view; common, comprehensive, cooperative and sustainable security view; open, inclusive, mutually beneficial and win-win cooperation view; equality, mutual learning, dialogue and inclusive civilization view; extensive consultation, joint contribution and shared benefits global governance view. The SCO community with a shared future built on the basis of the five views includes a five-in-one community with a shared future: economic community, a world of common prosperity; security community, a world of universal security; peace community, a world of lasting peace; civilization community, an open and inclusive world; ecological community, a clean and beautiful world.

In short, the 20-year development of the SCO has formed the "Shanghai Spirit", and in accordance with the innovation of practice and the requirements of the times, the "Shanghai Spirit" has been endowed with new connotation-the Five Views of the "Shanghai Spirit" (Xia \& Yun, 2019). The enrichment, en- 
hancement and development of the Shanghai Spirit "is of great significance to the international community's search for a new, non-confrontational model of international relations, which calls for abandoning the Cold War mentality and transcending ideological differences" (CMFA, 2006).

\subsection{The Enrichment and Improvement of Cooperation Mechanisms}

As a multilateral regional international organization, the SCO cooperation mechanism is an important support for its existence and development (Dadabaev, 2014). Twenty years, with the development of the international and regional situations, between the SCO member states within the organization in a safe, economic, political, social, and human all-round cooperation in various fields, cooperation issues gradually spread, cooperation behavior is becoming more transparent, cooperation attitude increasingly open, cooperation mechanism more enriched.

Over the past two decades, the SCO has been operating on the basis of its organizational structure and has formed a mechanism of meeting and cooperation. According to the provisions of the SCO charter, the organizational structure of the SCO mainly includes various institutions and some specialized organizations. Among them, the SCO is mainly composed of conference bodies and permanent bodies. The conference bodies include the meeting of heads of state, the meeting of heads of government (Prime Ministers), the meeting of ministers of foreign affairs, the meeting of heads of ministries, the council of national coordinators, etc. Permanent bodies refer specifically to secretariats and regional counter-terrorism bodies. In addition, in accordance with the development of the situation and the different requirements of specific fields of expertise, the SCO has also established a number of non-governmental professional organizations, such as observer delegation mechanism, interbank association, business council, SCO forum, etc. (Zhu \& Wei, 2017). In terms of operating mechanism, it mainly includes three parts: conference mechanism, professional mechanism, observer state mechanism and partner state mechanism. Over the past two decades, the SCO has developed meeting mechanisms of various sizes, and meetings of various types and levels, mainly including: SCO summit, the prime minister regular meetings, parliament meetings, defense ministers meetings, foreign ministers meeting, the supreme court and the attorney general meetings, interior minister of public security meetings, the transport ministers meetings, culture minister meetings, economic and trade ministers meeting, finance ministers and central bank governors meetings, justice and security council secretary meetings and SCO member states joint military exercises and other activities. Specialized mechanisms, such as SCO forum, address problems in specialized areas; the observer state mechanism and the dialogue partner mechanism are aimed at extensive contact and cooperation with other countries.

In brief, guided by a new type of state-to-state relations, the SCO cooperation 
organization has established a new type of regional multilateral cooperation mechanism. The SCO is different from a traditional alliance or a regional organization with management functions. It is based on reality and feasibility and creates an effective mode of regional cooperation that suits the characteristics of the region. It is both realistic and future-oriented and focuses on the region and the world at large (Zhang, 2020).

\subsection{The Extension of Cooperation Areas}

The SCO has grown from security cooperation to political, economic, cultural and people-to-people cooperation. It is fair to say that security cooperation is one of the original driving forces for the formation of the SCO as a regional organization. It is also the most cohesive and vigorous area of cooperation of the SCO (Wang \& Kon, 2019). With the development of the SCO, the scope of cooperation has been constantly expanded, and cooperation has taken shape in political, economic, military, cultural and other fields on the basis of security cooperation. Multi-dimensional cooperation has become an important driving force for the further development of the SCO.

Defense and security cooperation is a priority area of SCO cooperation, and is a major driving force for the SCO's development. SCO security cooperation includes traditional security and non-traditional security. Traditional security cooperation mainly includes ensuring border security, military exchanges, military exercises and other military mutual trust practices. Non-traditional security cooperation is a major part of the security cooperation among SCO member states, which is mainly manifested in joint efforts to combat the "three forces" of terrorism, extremism and separatism, and crack down on drug trafficking, transnational crimes and illegal immigration (Emilian, 2012). Currently, SCO security cooperation is focused on non-traditional security areas, while non-traditional security cooperation is mainly focused on counter-terrorism cooperation. As early as the Shanghai Five, the predecessor of the SCO, carried out counter-terrorism cooperation. When the SCO was established in 2001, it issued the Shanghai Convention on Combating Terrorism, Separatism and Extremism, laying a solid foundation for joint counter-terrorism efforts. Since the September 11 attacks, the SCO has strengthened anti-terrorism cooperation in legal basis, institutional framework and anti-terrorism exercises. With the advent of the information age, terrorism has also begun to grow with the help of the Internet, which breeds network terrorism. The heads of state council of SCO member states in 2020 issued "the statement to crack down on using the Internet and other channels to spread of terrorism, separatism and extremism", which points out that in the SCO regional anti-terrorism organization framework, it is very important to exchange information to found that using the Internet to promote terrorism, division and extreme activities, competent authorities of member states should be supported in deepening cooperation in this field (CMFA, 2020b). It is fair to say that over the past 20 years, the SCO has been deeply engaged in coun- 
ter-terrorism cooperation. Adhering to joint counter-terrorism and coordinated actions, it has achieved remarkable results and effectively safeguarded security and stability in central Asia.

Actively promoting practical cooperation in various fields is an important development direction of the SCO. The SCO needs to further expand cooperation areas on the basis of deepening security cooperation. At present, SCO cooperation has expanded to multi-field and multi-level cooperation, specifically, in terms of political cooperation, which mainly focuses on solving boundary issues and consolidating political mutual trust and good-neighborliness among SCO member states. They expressed support in the name of the SCO on issues of concern to the member states. The member states elaborated on many occasions their common position on Afghanistan, the Palestinian-Israeli conflict, Iraq, the Korean Nuclear issue and other issues. On the reform of the UN Security Council, The Astana summit declaration stressed that reforms should follow the principle of the broadest consensus, and that deadlines should not be set and significant differences should not be forced to vote. In terms of economic cooperation, which covering trade and investment, customs, finance, taxation, transportation, energy, agriculture, economy, finance, investment and other fields. As digital technology has become an important engine for economic development, there is great potential for cooperation in the field of digital transformation. The SCO points out the importance of enhancing all-round cooperation in the field of digitalization and narrowing the digital divide in economic development (CMFA, 2020c). In terms of educational cooperation, at the SCO Heads of State Summit in Bishkek in 2007, the President of Russia Vladimir Putin proposed the establishment of the SCO University, which was unanimously endorsed by all member states. At present, there are 74 SCO universities under the program, 14 in Kazakhstan, 20 in China, 9 in Kyrgyzstan, 21 in Russia and 10 in Tajikistan. To cite here only in a lapidary way: Astrakhan State University, Russian People's Friendship University, Ural Federal University, Bishkek Humanities University, Xinjiang University, Dalian University of Foreign Languages, Harbin Institute of Technology, Northeast Normal University, Satbayev Kazakh National Technical University, Karaganda State Technical University, S. Toraighyrov Pavlodar State University, M.Auezov South Kazakhstan State University, Kyrgyz State Technical University, Osh State University and Tajikistan University of Technology. These universities, which are part of the SCO University networks, implement educational programs that focus on the following areas: Information Technology, Nanotechnology, Pedagogy, Regional Studies, Ecology, Economics, Energy (URFU, 2015). In terms of public health cooperation, following the outbreak of COVID-19 in 2020, the SCO focused on public health cooperation, stressing that the SCO should strengthen cooperation in the field of public health, coordinate and coordinate measures to respond to emergencies in the field of health and epidemic prevention, and strengthen scientific and technological cooperation in drugs, vaccines and testing reagents (CMFA, 2020a). This is why, despite the difficulties and critical states that some of its member states found themselves in 
during this COVID-19 pandemic [to mention here only the cases of China, India and Russia], they were able to quickly see the light at the end of the tunnel. It is indeed an overall success in this health field of the SCO under the wind of COVID-19 after going through the great fear and uncertainty. This is mainly due to the hope that China has given following its resilience and quick rebound from the COVID-19. China's quick discharge from the weight of the COVID-19 has served as a relief to other SCO member states, especially through the sharing of its experience, and also its preparatory role in the distribution and sharing of some medical materials, basic necessities and various aids between them, the SCO member states: such as masks, respirators and others ... (RNA, 2020).

\section{Major Challenges}

Over the past 20 years since its establishment, the SCO has developed and improved its cooperation concept, operation mechanism and cooperation areas, and made remarkable achievements in practice, such as border disputes, combating the "three evil forces" [terrorism, separatism, and extremism], and increasing economic cooperation within and between its member states and across the region. However, the SCO also faces challenges and development difficulties on its way forward. We have been able to identify three of its major challenges that we want to outline here successively in this point, namely: The intensification of great power game (i), the weakness of the sense of community (ii) and the transformation of cooperation pattern faces after expansion (iii).

\subsection{The Intensification of Great Power Game}

At present, there are four great powers in and outside the SCO region: the United States, China, Russia and India. Among them, the United States is well a major power outside the region; China, Russia and India are rather major countries within the region. The United States is stepping up its competition in Central Asia (Fredholm, 2013; Rowden, 2018). As for the establishment and development of the SCO, some Western scholars, mainly from the United States, have made a realistic interpretation, pointing out that the SCO is a product of regional rivalry under the new international pattern and the international situation, a reproduction of the Warsaw Organization, and a "club of centralists" from the perspective of geographical location and membership (Kagan, 2008). The essence of the SCO is still a traditional regional security cooperation organization and a geopolitical weight for China and Russia to challenge the Western world led by the United States in central Asia (Blank, 2005; McDermott, 2012). Thus, in the past 20 years since the establishment of the SCO, the United States has stationed troops in Afghanistan under the pretext of "anti-terrorism" and intensified its competition in Central Asia. After Biden took office, the United States withdrew troops from Afghanistan, but did not relax its scramble for Central Asia. The United States, through the Trump administration, has successively launched the so-called Indo-Pacific Strategy, which implies that India, the United States, and other major Asian democracies, including Japan and Australia, 
will join together to contain the rise of China in the new framework of growing influence that speaks of the "New Cold War" (Chen, 2018; Makengo, 2020). Also, the New Afghanistan strategy, is a comprehensive regional strategy, which called for a shift from a time-based approach to one based on battlefield conditions; the use of all the tools of American power: diplomatic, economic and military; and "crushing Pakistan and supporting India" in Afghanistan. These are to enable the United States to achieve significant results in Afghanistan; to avoid an abrupt withdrawal from Afghanistan that could create a vacuum in Afghanistan for the reproduction of terrorism; to prevent the revival of terrorist sanctuaries that threaten U.S. security and the flow of weapons and nuclear materials into the hands of terrorists and enemies; and to impose U.S. leadership in the region (Tian, 2018). And the New Central Asia Strategy, which re-emphasizes the so-called "holy trinity": strong the United States support for the independence, sovereignty, and territorial integrity of all Central Asian nations, whose objects were: supporting and strengthening the sovereignty and independence of Central Asian states, individually and as a region; reducing terrorist threats in Central Asia; expanding and sustaining support for stability in Afghanistan; fostering connectivity between Central Asia and Afghanistan; promoting rule of law reform and respect for human rights; and promoting the United States investment in and development of Central Asia. These were in keeping with the logic of allowing the United States to retain influence and interest in Central Asia after the departure of U.S. forces in the region (Putz, 2020). Again, the United States has also strengthened the " $\mathrm{C} 5+1$ " mechanism with Central Asian countries and intensified its efforts to contain and suppress China and Russia, intensifying the dispute over order in Central Asia (Rowden, 2018). Moreover, in order to compete with China for dominance in Central Asia, the United States has hyped up Xinjiang-related issues, smearing China's image and alienating relations between China and Central Asian countries. It is fair to say that the great power competition that the United States is determined to instill in the SCO region has greatly worsened the external environment of the SCO and put the SCO under unprecedented geopolitical pressure (Hao, 2021).

\subsection{The Weakness of the Sense of Community}

The SCO currently comprises eight member states: China, Russia, India, Pakistan, Kazakhstan, Kyrgyzstan, Tajikistan and Uzbekistan. The concrete structure of the eight member states is " $3+5$ " [three big countries plus five small and medium-sized countries]. Although the eight-member SCO is guided by the "Shanghai Spirit" and the SCO community with a shared future, generally speaking, the awareness of the SCO community with a shared future is still relatively weak. Specific performance is as follows: First, the game between China, Russia and India has weakened the SCO's sense of community to some extent. China, Russia and India are all big countries. They all want to exert their status and influence in the SCO and try to play a key leading role in the development of the SCO. Second, the national strategies of the five small and medium-sized 
SCO countries focus on their own development and give more consideration to their national interests. The four Central Asian member states, which gained independence after the collapse of the Soviet Union, cherish their hard-won status of independence and sovereignty. They always put their own interests above everything else and have no intention to cede more rights to the SCO. All these are not conducive to the establishment of a collective identity and common goals of the SCO (Hao, 2021). As a developing country, Pakistan's strategic focus is on domestic development, and its motivation for joining SCO is to rely on this regional international organization to provide security guarantee and development impetus for itself. Third, the operating mechanism of the SCO has, to some extent, restricted the sense of community. At present, the SCO adheres to the "consensus" decision-making mechanism, which greatly limits the decision-making efficiency and action of the SCO. As a result, it is difficult for the SCO to respond promptly and effectively to member states and major political events in the region-that just shows the weaknesses of its community sense. The bottom line here is that the SCO's sense of community still really needs to be strengthened.

\subsection{The Transformation of Cooperation Pattern Faces after Expansion}

In June 2017, the Astana Summit of the SCO officially admitted India and Pakistan as two new member states, achieving the first expansion of the SCO since its establishment and increasing the number of full member states to eight. With the accession of India and Pakistan as two new full member states, the number of SCO member states should increase, while the collision of interests and role positioning among member states should also undergo corresponding changes. Moreover, the cohesion and centripetal force within the SCO should only encounter new shocks (Boyi \& Dekai, 2020), and the cooperation pattern of the SCO should also be transformed.

Before the expansion of the SCO, the SCO cooperation framework was a pattern of equal participation among member states led by China and Russia, namely the " $2+4$ " pattern [China, Russia plus Central Asian members]. On the one hand, SCO cooperation practices insist on equal participation and joint leadership by member states. When making decisions, the SCO adheres to the principle of equality and consensus. Every member state has veto power, and the four central Asian member states have equal status with China and Russia, as well as the opportunity to practice multilateral balanced diplomacy (Renwick, 2008; Li, 2021). Of course, among the six SCO member states before its expansion, China and Russia, as world powers, are far ahead of the other four Central Asian states in terms of national strength, status and influence. Therefore, in order to ensure the legitimacy, effectiveness and sustainability of the SCO, China, Russia and central Asian member states have formed a pattern of cooperation within the SCO featuring "leading by major countries and equal participation by 
small and medium-sized countries" (Li, 2021).

Under the principle of consensus within the SCO framework, China and Russia provide the SCO with major capacity and influence and lead the Central Asian member states to participate in cooperation. For example, China and Russia bear a large proportion of the SCO's financial and material support, and provide important cooperation ideas and practical proposals for the SCO's development.

After the expansion of the SCO, the cooperation pattern of "major powers leading" in the SCO is put to the test. Since the expansion of SCO membership, its internal power structure has undergone significant changes and its internal cooperation pattern has further increased in complexity. In 2017, the SCO admitted two countries, India and Pakistan. The inclusion of India as a member has broken the "two-engine" pattern of China and Russia. As a major country in South Asia, India's accession directly leads to changes in the relations between major countries in SCO: from bilateral relations between China and Russia to trilateral relations between China, Russia and India; from the "two carriages" of China and Russia to the "strategic triangle" of China, Russia and India; from one group of major powers, China and Russia, to three groups of major powers, China and Russia and India (Rowden, 2018). Moreover, one of India's strategic demands for joining the SCO is to prevent China from being "dominant" in Central Asia, and the complex relations of competition and cooperation between China and India affected the SCO's development to a certain extent. Thus, the expansion of the SCO has added to the complexity of relations between major powers within the organization. But rather, the basic framework under which the "two carriages" of China and Russia jointly lead the development of the SCO has not changed significantly-at present, China-Russia relations are at their best in history.

\section{Prospects}

Currently, the SCO is at a critical juncture of building on past achievements and forging ahead into the future. The future direction of the SCO must be mapped out in advance, both from the external environment and with a view to its own development. As a regional multilateral international organization that has been responsible for regional governance since its inception, the SCO is fully likely to play a greater role and make greater achievements in the future. We project here in succession three great directions, in the form of directive thoughts, that explore the path for further development of the, namely: The Shanghai spirit provides direction for multilateral cooperation (i), the SCO mechanism provides important guarantee for multilateral cooperation (ii) and a new type of international relations as an important driving force for multilateral cooperation (iii).

\subsection{The Shanghai Spirit Provides Direction for Multilateral Cooperation}

The "Shanghai spirit" proposed by the SCO is completely different from the 
ideas of previous Western-led international organizations. It rejects the traditional theories and modes of thinking on international relations such as zero-sum game, Cold War mentality and clash of civilizations, and the "five views" advocated by the SCO has won wide support and recognition from the member states. The Shanghai spirit, with the five views as its core, has led the SCO to create a new model of international relations featuring partnership rather than alliance and cooperation rather than confrontation (Fredholm, 2013). The Shanghai Spirit put forward and practiced by the SCO is an innovative and useful exploration of establishing a fair and equitable order in central Asia and the international political and economic order. It provides useful lessons for regional and even global governance in the face of profound change. The "Shanghai Spirit" is integrated with the "two constructs" of building a new type of international relations and a community with a shared future (Yang, 2015; Makengo, 2020). It represents the trend of the times and the aspirations of developing countries, and contributes new wisdom and ideas to regional governance under the new circumstances. It will help change the fragmentation of regional governance and even global governance. Building a new international order that better reflects the rights and interests of developing countries and emerging countries is of great guiding and practical significance.

\subsection{The SCO Mechanism Provides Important Guarantee for Multilateral Cooperation}

Over the past 20 years since its establishment, the SCO has been actively and steadily advancing its development in accordance with the principle of seeking common ground while shelving differences and seeking mutual benefit and win-win results, thus forming the SCO mechanism (Fredholm, 2013; Fan, 2021). When the SCO was founded, it adopted the Shanghai Convention, which, for the first time in the world, clearly defined the concepts of terrorism, extremism and separatism, providing a legal basis for member states to jointly combat the "three forces". Since then, the SCO has constantly improved its laws, regulations and institutions on security cooperation, providing legal tools for security cooperation among member states and effectively maintaining security and stability in the SCO region. The SCO is also making steady progress in institutionalizing economic cooperation. At present, the SCO member states are actively negotiating and signing the Agreement on Trade Facilitation among the SCO member States and the Framework Agreement on Trade in Services among the SCO member states, which will lay an indispensable legal foundation for promoting regional trade facilitation. In addition, significant progress has been made in the institutionalization of the SCO in political and cultural fields. It is fair to say that the SCO has made remarkable achievements in cooperation mechanisms. On the one hand, it has provided an important guarantee for the SCO's development, and on the other hand, it has contributed the "SCO wisdom" and "SCO plan" to the international community. 


\subsection{A New Type of International Relations as an Important Driving Force for Multilateral Cooperation}

Over the past two decades, the SCO has been open to the outside world, guided by a new type of state-to-state relations, and actively building a network of multilateral partners. The new type of state-to-state relations featuring mutual respect and win-win cooperation is an important driving force for deepening SCO cooperation (Yang, 2015). To be specific, the new type of state-to-state relations of the SCO is mainly manifested in the following three aspects: First, the relations between the eight SCO member states. The SCO member states adhere to equality, mutual respect, fairness and justice regardless of size and strength, and solve traditional and non-traditional security issues through dialogue and consultation. Through openness and cooperation, to seek mutual benefit and win-win results and jointly promote development and prosperity in the SCO region. Second, the relations between member states, observer states and partner member states. At present, the SCO has eight member states, has four observer states including Afghanistan, Belarus, Iran and Mongolia and has six dialogue partners including Azerbaijan, Armenia, Cambodia, Nepal, Turkey and Sri Lanka. The SCO member states, as well as observer and partner member states, respect each other, consult on an equal footing, actively seek common interests and promote regional security, stability and prosperity. Third, the relations between SCO and the United Nations and other global and regional international organizations. Over the past two decades, the SCO has always upheld the authority of the United Nations, actively established contacts and conducted cooperation with the United Nations and its branches, and actively fostered a new type of international relations. In 2004, the SCO become UN observers, get involved in the rights of the General Assembly and work since then, the SCO carried out effective cooperation with some UN branches, such as the UN office on drugs and crime, the Secretariat of the United Nations Economic and Social Commission for Asia and the Pacific, the United Nations Educational, Scientific and Cultural Organization, the UN Security Council Anti-Terrorism Commission and the United Nations Development Program (UNDP) (Hao, 2020). All in all, cooperation within the SCO and with the UN and other international organizations is based on mutual respect, openness, inclusiveness and mutual benefit, which provides inexhaustible impetus for the development of the SCO.

\section{Conclusion}

The findings of this paper show that over the past 20 years since the SCO establishment in June 2001, its concept of cooperation has been constantly enriched and developed. Its cooperation mechanism has been constantly enriched and improved; and its areas of cooperation have been expanded. However, following its development over time and the advancement of its cooperation practices, it also faces challenges and development difficulties on its way forward; these include the facts of: the intensification of great power game in the region, the 
weakness of the sense of community between its member states and the transformation of cooperation pattern faces after expansion. With regard to its prospects, the Shanghai spirit will guide its multilateral cooperation vision. Also, the SCO mechanism provides an important guarantee for multilateral cooperation ahead. The new type of international relations will serve as an important driving force for its multilateral cooperation vision. Finally, based on our results, we believe that the SCO is fully capable of exerting greater influence and delivering greater results in the years to come.

\section{Conflicts of Interest}

The authors declare no conflicts of interest regarding the publication of this paper.

\section{References}

Blank, S. (2005). The Central Asian Dimension of Russo-Chinese Exercises. Central Asia-Caucasus Analyst.

Boland, J. (2011). Ten Years of the Shanghai Cooperation Organization: A Lost Decade? A Partner for the U.S. (pp. 1-62)? Foreign Policy at Brookings, 21st Century Defense Initiative Policy Paper.

Boyi, L., \& Dekai, H. (2020). Difficulties and Prospects of the Shanghai Cooperation Organization. Strategic Decision Research, 93, 85-104.

Chen, D. (2018, June 4). The Indo-Pacific Strategy: A Background Analysis. Istituto per gli Studi di Politica Internazionale.

https://www.ispionline.it/it/pubblicazione/indo-pacific-strategy-background-analysis-2 $\underline{0714}$

China Ministry of Foreign Affairs (CMFA) (2006). Declaration on the Fifth Anniversary of the Shanghai Cooperation Organization.

http://office-macau.fmprc.gov.cn/web/ziliao 674904/1179 674909/t346575.shtml

China Ministry of Foreign Affairs (CMFA) (2016). Tashkent Declaration on the 15th Anniversary of the Shanghai Cooperation Organization (Full Text).

https://www.fmprc.gov.cn/web/gihdq 676201/gjhdqzz 681964/lhg 683094/zywj 6831 06/t1375252.shtml

China Ministry of Foreign Affairs (CMFA) (2020a). Statement of the Council of Heads of the Shanghai Cooperation Organization Member States on Joint Response to the New Coronary Pneumonia Epidemic. http://new.fmprc.gov.cn/web/zyxw/t1831164.shtml

China Ministry of Foreign Affairs (CMFA) (2020b, November 10). Statement of the Council of Heads of States Members of the Shanghai Cooperation Organization on Combating the Use of the Internet and Other Channels to Spread Terrorist, Separatist and Extremist Ideas.

https://www.fmprc.gov.cn/web/ziliao 674904/1179 674909/t1831181.shtml

China Ministry of Foreign Affairs (CMFA) (2020c). Statement of the Council of Heads of State of the Shanghai Cooperation Organization on Cooperation in the Field of Digital Economy.

https://www.fmprc.gov.cn/web/ziliao 674904/1179 674909/t1831181.shtml

Dadabaev, T. (2014). Shanghai Cooperation Organization (SCO) Regional Identity Formation from the Perspective of the Central Asia States. Journal of Contemporary China, 23, 102-118. https://doi.org/10.1080/10670564.2013.809982 
Efremenko, D. V. (2019). New Stage in the Development of the Shanghai Cooperation Organization. China in World and Regional Politics: History and Modernity, No. 25, 114-130.

Emilian, K. (2012). L.C. Kumar, Shanghai Cooperation Organization: Eurasian Security through Cooperation. Europe-Asia Studies, 64, 387-388.

https://doi.org/10.1080/09668136.2011.646495

Fan, X. (2021). Existing Mechanisms of the Shanghai Cooperation Organization and Their Problems Dealing with Non-Traditional Security Challenges. International Organizations Research Journal, 16, 107-126. https://doi.org/10.17323/1996-7845-2021-01-05

Fredholm, M. (Ed.) (2013). The Shanghai Cooperation Organization and Eurasian Geopolitics New Directions, Perspectives, and Challenges (pp. 1-324). Nordic Institute of Asian Studies.

Germanovich, G. (2008). The Shanghai Cooperation Organization: A Threat to American Interests in Central Asia? China and Eurasia Forum Quarterly, 6, 19-38.

Hao, D. (2020). The Shanghai Cooperation Organization and Global Governance in the New Era. China International Studies, No. 4, 149-173.

Hao, D. (2021). SCO Political Cooperation: Progress, Challenges and Future Paths. International Studies, No. 3, 47-66.

International Institute for Strategic Studies (IISS) (2018). The Evolution of the Shanghai Cooperation Organisation. Strategic Comments, 24, 7-9.

https://doi.org/10.1080/13567888.2018.1495424

Jia, Q. G. (2007). The Shanghai Cooperation Organization: China's Experiment in Multilateral Leadership. In I. Akihiro (Ed.), Eager Eyes Fixed on Eurasia: Russia and Its Eastern Edge (pp. 113-123). Slavie Research Center, Hokkaido University.

Kagan, R. (2008). The Return of History and the End of Dreams. Knopf.

Li, X. T. (2021). The Regional Positioning and Cooperation Pattern of the Shanghai Cooperation Organization after Expansion. International Outlook, 102, 96-118.

Makengo, B. M. (2020). Globalization and Power Strategies: A Look at the US-China Trade War. International Journal of Management Sciences and Business Research, 9, 117-143.

McDermott, R. N. (2012). The Shanghai Cooperation Organization's Impact on Central Asian Security. Problems of Post-Communism, 59, 56-65.

https://doi.org/10.2753//PPC1075-8216590405

Putz, C. (2020). A New US Strategy for Central Asia: Continuity under Better Conditions. The Diplomat.

https://thediplomat.com/2020/02/a-new-us-strategy-for-central-asia-continuity-underbetter-conditions/

Renwick, N. (2008). Contesting East Asian Security Leadership: China and the Shanghai Cooperation Organisation. In C. M. Dent (Ed.), China, Japan and Regional Leadership in East Asia (pp. 219-222). Edward Elgar Publishing. https://doi.org/10.4337/9781848442795.00022

Rowden, R. (2018). The Rise and Rise of the Shanghai Cooperation Organisation (pp. 1-13). Sheffield Political Economy Research Institute Interdisciplinary Centre of the Social Sciences.

Russian News Agency (RNA) (2020, September 10). Fight against COVID-19 within SCO Is More Effective than in Other Regions, Says SCO Chief.

https://tass.com/economy/1199125 
SCO (Shanghai Cooperation Organisation) (2021). The Shanghai Cooperation Organisation. http://eng.sectsco.org/about sco/

Tian, G. Q. (2018). Valuation of Trump's Administration's New Afghanistan Strategy: Content, Background and Challenges. Academic Exploration.

Ural Federal University (URFU) (2015, August 3). University of Shanghai Cooperation Organization (SCO University).

https://urfu.ru/en/international/international-projects/sco-university/

Wang, J., \& Kong, D. (2019). Counter-Terrorism Cooperation between China and Central Asian States in the Shanghai Cooperation Organization. China Quarterly of International Strategic Studies, 5, 65-79.

https://doi.org/10.1142/S2377740019500027

Xia, L., \& Yun, X. (2019). The New Connotation of "Shanghai Spirit" and Building a Community of Human Destiny. Journal of Shanghai Jiaotong University (Philosophy and Social Science Edition), 27, 26-36.

Yang, J. C. (2015). A New Type of International Relations: Writing a New Chapter of Win-Win Cooperation. Horizons, No. 4, 12-19.

Zhang, Y. L. (2020). Shanghai Cooperation Organization: Exploring the Way to Get along in the New Era. World Knowledge, No. 14, 72.

Zhu, Y. B., \& Wei, Y. Y. (2017). Analysis of the Development Stages and Prospects of the Shanghai Cooperation Organization-Based on the Perspective of Organizational Life Cycle Theory. Contemporary Asia-Pacific, No. 3, 34-54, 158. 